\title{
SELF CARE MANAGEMENT EVALUATION IN HYPERTENSION PATIENTS
}

\author{
Raja Sihotang ${ }^{1}$, Tuti Anggraini Utama ${ }^{2}$, Titin Aprilatutini ${ }^{2}$, Nova Yustisia ${ }^{3}$ \\ ${ }^{1234}$ Program Studi D3 Keperawatan Univesitas Bengkulu \\ Email Korespondensi: tautama@unib.ac.id
}

\begin{abstract}
Hypertension is a health problem that needs attention because of its high morbidity and mortality. hypertension must be treated properly because it causes various kinds of complications. Compliance becomes a form of independence in the management of patients, especially those with hypertension, in the form of a framework that focuses on selfcare. The purpose of this study is to review the literature to determine the percentage of self care management of hypertensive patients. The literature search method was carried out through the CINAHL, DOAJ, and Pubmed database and obtained 30 research articles and then examined the completeness of the menus in the research articles with a total of 15 articles. After that, the criteria and stages of critical review were carried out using the Joanna Briggs Institute (JBI) format with a total of 10 articles that were reviewed by literature. The results showed that hypertension self management was in the good category. Further research is needed to provide an intervention strategy for hypertensive patients to improve self-care practices and control of related factors.
\end{abstract}

Keywords: evaluation, self care management, hypertension

\section{PENDAHULUAN}

Penyakit jantung dan pembuluh darah (kardiovaskuler) merupakan masalah kesehatan utama di negara maju maupun negara berkembang dan menjadi penyebab kematian nomor satu di dunia setiap tahunnya. Hipertensi merupakan salah satu penyakit kardiovaskular yang paling umum dan paling banyak disandang masyarakat. Data World Health Organization (WHO) tahun 2015 menunjukkan sekitar 1,13 Miliar orang di dunia menyandang hipertensi, artinya 1 dari 3 orang di dunia terdiagnosis hipertensi. Jumlah penyandang hipertensi terus meningkat setiap tahunnya, diperkirakan pada tahun 2025 akan ada 1,5 Miliar orang yang terkena hipertensi, dan diperkirakan setiap tahunnya 10,44 juta orang meninggal akibat hipertensi dan komplikasinya (P2PTM Kemenkes RI, 2019). 
Estimasi jumlah kasus hipertensi di Indonesia sebesar 63.309.620 orang, sedangkan angka kematian di Indonesia akibat hipertensi sebesar 427.218 kematian. Hipertensi terjadi pada kelompok umur 31-44 tahun (31,6\%), umur 45-54 tahun (45,3\%), umur 55-64 tahun (55,2\%). Hipertensi disebut sebagai the silent killer karena sering tanpa keluhan, sehingga penderita tidak mengetahui dirinya menyandang hipertensi dan baru diketahui setelah terjadi komplikasi.

Hipertensi dapat dicegah dengan mengendalikan perilaku berisiko seperti merokok, diet yang tidak sehat seperti kurang konsumsi sayur dan buah serta konsumsi gula, garam dan lemak berlebih, obesitas, kurang aktifitas fisik, konsumsi alkohol berlebihan dan stress dengan self care management. Data Riskesdas 2018 pada penduduk usia 15 tahun keatas didapatkan data faktor risiko seperti proporsi masyarakat yang kurang makan sayur dan buah sebesar 95,5\%, proporsi kurang aktifitas fisik $35,5 \%$, proporsi merokok $29,3 \%$, proporsi obesitas sentral $31 \%$ dan proporsi obesitas umum $21,8 \%$.

Upaya yang telah dilakukan dalam pencegahan dan pengendalian Hipertensi diantaranya adalah meningkatkan promosi kesehatan melalui KIE dalam pengendalian Hipertensi dengan perilaku "CERDIK" (C = Cek kesehatan secara berkala, $\mathrm{E}=$ Enyahkan asap rokok, $\mathrm{R}=$ Rajin aktifitas fisik, $\mathrm{D}=$ Diet sehat dengan kalori seimbang, $\mathrm{I}=$ Istirahat cukup dan $\mathrm{K}=$ Kelola stress.) dan "PATUH" (P : Periksa kesehatan secara rutin dan ikuti anjuran dokter atau petugas kesehatan. A : Atasi penyakit dengan pengobatan yang tepat dan teratur, $\mathrm{T}$ : Tetap diet dengan gizi seimbang, U : Upayakan aktifitas fisik dengan aman dan H : Hindari asap rokok, alcohol dan zat karsinogenik lainnya.), meningkatkan pencegahan dan pengendalian Hipertensi berbasis masyarakat dengan "Self Awareness" melalui pengukuran tekanan darah secara rutin, penguatan pelayanan kesehatan khususnya Hipertensi, pemerintah telah melakukan berbagai upaya untuk meningkatakan hal tersebut. (P2PTM Kemenkes RI, 2019). 
Hipertensi sering kali dialami tampa keluhan adalah masalah utama sehingga terjadinya komplikasi. Self care management sangat berpengaruh besar dalam pengendalian resiko komplikasi hipertensi. Tujuan penelitian ini untuk mengevaluasi variabel self care management pasien hipertensi dengan metodologi penulisan yang digunakan adalah studi literatur review.

\section{LITERATURE REVIEW}

Hipertensi secara sederhana adalah tekanan darah tinggi. Ini didefinisikan sebagai peningkatan tekanan darah sistolik persisten pada level $140 \mathrm{~mm} \mathrm{Hg}$ atau lebih tinggi dan tekanan darah diastolik pada level $90 \mathrm{~mm} \mathrm{Hg}$ atau lebih tinggi. (Black dan Hawks, 2009). Hipertensi adalah tekanan darah tinggi yang abnormal dan diukur paling tidak pada tiga kesempatan yang berbeda. Tekanan darah normal bervariasi sesuai usia, sehingga setiap diagnosis hipertensi harus bersifat spesifik usia. Tekanan arteri disebut normal jika tekanan sitolik $<120 \mathrm{mmHg}$ (tapi $>90 \mathrm{mmHg}$ ) dan tekanan diastolik <80 mmHg (tapi>60mmHg). Tekanan diastolik antara 80 sampai $89 \mathrm{mmHg}$ dan tekanan sistolik antara 120 sampai 139 mmHg dianggap sebagai prehipertensi. Hipertensi diastolik telah terbukti sebagai faktor risiko nyata untuk gangguan kardiovaskular lain seperti stroke dan infark miokard (Richard, 2015).

Hipertensi sering diklasifikasi menjadi hipertensi primer dan hipertensi sekunder, berdasarkan ada tidaknya penyebab yang dapat diidentifikasi (LeMone, 2019). Hipertensio primer disebabkanr sejumlah faktor resiko seperti riwayat keluarga, usia, ras, asupan mineral, kegemukan, resistensi insulin, konsumsi alkohol berlebihan, dan stress. Hipertensi sekunder disebabkan oleh penyakit ginjal, koartasio aorta, gangguan endokrin, gangguan neurologis, pemakaian obat dan kehamilan.

Hipertensi menetap memengaruhi sistem kardiovaskular, saraf, dan ginjal. Laju aterosklerosis meningkat, meningkatkan risiko penyakit jantung koroner dan stroke. Beban kerja ventrikel kiri meningkat, menyebabkan hipertrofi ventrikel, yang kemudian meningkatkan risiko penyakit jantung koroner, disritmia, dan gagal 
jantung. Tekanan darah diastolik adalah faktor risiko kardiovaskular signifikan sampai usia 50 tahun; tekanan sistolik kemudian menjadi faktor yang lebih penting yang menyebabkan risiko kardiovaskular (National Heart, Lung, and Blood Institute dalam LeMone, 2019). Sebagian besar kematian akibat hipertensi disebabkan oleh penyakit jantung koroner dan infark miokardium akut atau gagal jantung.

Canadian Hypertension Education Program (2005) merekomendasikan beberapa penatalaksanaan hipertensi antara lain : memodifikasi gaya hidup (di dalamnya termasuk modifikasi diet, penurunan berat badan, dan aktivitas) merupakan strategi yang efektif untuk menurunkan tekanan darah dan menurunkan faktor resiko, penggunaan statin dan acetylsalicylic acid (ASA) merupakan bagian dari strategi perlindungan kardiovascular pada pasien hipertensi, angiotensin Converting Enzyme (ACE) inhibitors untuk pasien dengan atherosklerosis, ACE inhibitor atau angiotensin II Receptor Blocker (ARB) untuk klien dengan diabetes dan penyakit ginjal.” Tujuan dari penatalaksanaan hipertensi adalah untuk mencegah terjadinya morbiditas dan mortalitas dari hipertensi. Black \& Hawks (2009) menjelaskan tujuan dari penatalaksanaan hipertensi adalah menormalkan tekanan darah dan menurunkan faktor resiko dalam usaha pengendalian keparahan hipertensi. Tujuannya adalah untuk menurunkan tekanan sistolik dibawah $140 \mathrm{mmHg}$ (target $=120 \mathrm{mmHg}$ ) dan tekanan diastolik di bawah $90 \mathrm{mmHg}$ (target $=80 \mathrm{mmHg}$ ) dengan memodifikasi dan mengendalikan faktor resiko.

Penatalaksanaan hipertensi meliputi: modifikasi gaya hidup. Efektivitas gaya hidup bersamaan dengan terapi farmakologis dalam pencegahan dan manajemen awal hipertensi telah didokumentasikan dalam literatur (CHEP, 2005; NIH, 2003;. Williams et al, 2004). Pada penelitian yang dilakukan oleh Rigsby (2011) tentang modifikasi gaya hidup pada pasien hipertensi menunjukkan bahwa secara umum pada pasien yang mengadopsi gaya hidup sehat memiliki peningkatan kemampuan dalam pengendalian tekanan darah. Modifikasi gaya hidup seperti makan-makanan sehat dan aktivitas fisik merupakan bagian dari peningkatan pengendalian tekanan darah. 
Penatalaksanaan kedua adalah penurunan berat badan. Peningkatan berat badan ditunjukkan dengan tingginya indeks masa tubuh dengan nilai 27 atau lebih hal ini memiliki hubungan dengan peningkatan tekanan darah (Black \& Hawks, 2009). Menurut Starnznicky, et al (2010) dalam Casey (2011) penurunan berat badan $10 \mathrm{~kg}$ dapat menurunkan tekanan darah sistolik 5-20 mmHg, metode penurunan berat badan dapat dilakukan dengan modifikasi diet dan Exercise. Penatalaksanaan ketiga adalah modifikasi diet. Terapi diet bertujuan untuk mengurangi lemak adalah sangat penting ditambahkan dalam regimen diet. DASH (dietary approaches to stop hypertension) yang terdiri dari buah, sayuran, kacang-kacangan dan makanan rendah lemak bisa direkomendasikan untuk klien yang membutuhkan struktur diet lebih serta pembatasan lemak (Black \& Hawks, 2009). Penelitian tersebut menunjukkan diet DASH dengan pengurangan asupan natrium telah mengurangi tekanan darah sebesar 11.5/5.7 mmHg (sistolik / diastolik), yang setara dengan perubahan yang terlihat dengan obat antihipertensi. Exercise program merupakan penatalaksanaan hipertensi. Latihan aerobik yang teratur cukup adekuat untuk mencapai kebugaran dan dapat membantu pasien hipertensi dalam menurunkan berat badan dan menurunkan resiko penyakit kardiovaskular.

Self care management juga merupakan penatalaksanaan hipertensi. Lee, et al. (2011) menjelaskan bahwa self care melibatkan perilaku mencegah keparahan dan melibatkan proses pengambilan keputusan dimana pasien mampu mengevaluasi dan mengatasi gejala penyakit ketika terjadi. Self care management meliputi evaluasi gejala, penatalaksanaan gejala dan evaluasi perilaku penatalaksanaan. Self care management yang efektif berarti bahwa individu memiliki rasa tanggung jawab terhadap kesehatan mereka sendiri dan memiliki peran yang penting terhadap perawatan kesehatan mereka sendiri (Robert Wood Johnson Foundation, 2003 dalam Weinert, et al. 2010). Menurut Nwinee (2011) menjelaskan tentang aktivitas self care management pada pasien meliputi kegiatan management pasien dengan obat yang didapat, pemantauan kesehatan, pengaturan makanan dan olahraga sesuai petunjuk serta kegiatan untuk mencegah komplikasi. Dari definisi tersebut maka dapat 
dikaitkan dengan kegiatan self care management pada pasien hipertensi merupakan segala sesuatu yang berkaitan dengan upaya pasien dalam mngelola dirinya sendiri dan mempertahankan perilaku yang efektif dalam menghadapi penyakit hipertensi yang dialami. Kegiatan dalam self care management hipertensi meliputi penggunaan obat anti hipertensi secara benar, kegiatan untuk memantau tekanan darah dan gejala yang muncul terkait penyakit hipertensi, pengaturan diet yaitu diet yang sesuai untuk penatalaksaanaan hipertensi, melakukan olahraga sesuai petunjuk untuk menurunkan tekanan darah dan kegiatan untuk mencegah komplikasi yang berhubungan dengan hipertensi.

Self care management yang merupakan bentuk perilaku pasien hipertensi dalam melakukan pentalaksanaan hipertensi dipengaruhi oleh faktor internal (dari diri pasien sendiri) dan faktor eksternal yaitu dari lingkungan dalam hal ini terkait dengan dukungan social yang diterima oleh pasien hipertensi dalam penatalaksanaan hipertensi. Faktor Internal enurut Nwinee (2011) faktor internal atau yang berasal dari diri pasien dalam self care management terdiri dari keyakinan atau nilai terkait penyakit, efikasi diri dan pengetahuan. Faktor eksternal yang mempengaruhi pengetahuan seseorang adalah faktor lingkungan dan faktor budaya. Menurut Mariner yang dikutip Wawan (2010) lingkungan merupakan seluruh kondisi yang ada di sekitar manusia dan pengaruhnya yang dapat mempengaruhi perkembangan dan perilaku orang atau kelompok. Sistem sosial budaya yang ada di masyarakat dapat mempengaruhi dari sikap dalam menerima informasi.

\section{METODE}

Penelitian ini adalah penelitian literatur review. Pencarian artikel self care hipertensi dimulai pada tanggal 19 april 2020 dengan menggunakan pencarian melalui basis data CINAHL, DOAJ, dan Pubmed dengan menggunakan kata kunci self-care AND hypertension dan didapatkan 30 artikel penelitian dari beberapa jurnal di semua basis data pencarian. Kemudian diperiksa berdasarkan kelengkapan penyusunan artikel 
penelitian dengan jumlah artikel yang didapatkan sebanyak 15 artikel. Setelah itu dilakukan tahap pemilahan berdasarkan kriteri inklusi: (1) Artikel penelitian berkaitan dengan perawatan diri, (2) Teks lengkap, (3) Publikasi 10 tahun terakhir dan kriteria eksklusi yaitu hanya sebatas surat ke editor. Artikel penelitian diambil berdasarkan kriteria inklusi dan didapatkan sebanyak 15 artikel penelitian. Sebanyak 15 artikel dilakukan penilaian kritis dengan menggunakan panduan atau format dari Joanna Briggs Institute (https://joannabriggs.org/critical_appraisal_to ols) dengan hasil yang didapatkan adalah 10 artikel penelitian yang relevan dan dilanjutkan dalam tinjauan literature.

\section{HASIL}

Tabel 1. Gambaran umum penelitian self care management pasien hipertensi

\begin{tabular}{|c|c|c|c|c|c|}
\hline No & Peneliti & Tujuan & $\sum_{\text {Sampel }}$ & $\begin{array}{c}\text { Disain } \\
\text { Penelitian }\end{array}$ & Hasil \\
\hline $\begin{array}{l}1 \\
.\end{array}$ & $\begin{array}{l}\text { Andy } \\
(2012)\end{array}$ & $\begin{array}{l}\text { Menganalisis faktor- } \\
\text { faktor } \\
\text { yang berhubungan } \\
\text { dengan self care } \\
\text { management pada } \\
\text { asuhan keperawatan } \\
\text { pasien hipertensi di } \\
\text { RSUD Kudus }\end{array}$ & 157 & $\begin{array}{l}\text { Cross } \\
\text { sectional }\end{array}$ & $\begin{array}{l}\text { Dalam analisa multivariat didapat } \\
\text { bahwa faktor yang paling } \\
\text { signifikan berhubungan dengan s } \\
\text { care management pasien } \\
\text { hipertensi di RSUD Kudus adalah } \\
\text { efikasi diri yang setelah dikontrol } \\
\text { pariabel pendidikan dan usia. }\end{array}$ \\
\hline $\begin{array}{l}2 \\
.\end{array}$ & $\begin{array}{l}\text { Widho } \\
\text { (2017) }\end{array}$ & $\begin{array}{l}\text { Penilaian gambaran } \\
\text { Self Care } \\
\text { pada penderita } \\
\text { Hipertensi di wilayah } \\
\text { kerja Puskesmas Gatak } \\
\text { kabupaten Sukoharjo }\end{array}$ & 61 & Deskriptif & $\begin{array}{l}\text { Gambaran self care pada pender } \\
\text { hipertensi di wilayah kerja } \\
\text { Puskesmas Gatak dengan hasil sebag } \\
\text { besar dengan kategori sedang yaitu } 3 \\
\text { responden }(57,4 \%) \text {. }\end{array}$ \\
\hline 3. & $\begin{array}{l}\text { Nargis } \\
(2010)\end{array}$ & $\begin{array}{l}\text { mengidentifikasi } \\
\text { tingkat manajemen } \\
\text { diri di antara pasien } \\
\text { dengan hipertensi } \\
\text { di Bangladesh }\end{array}$ & 110 & Deskriptif & $\begin{array}{l}\text { Hasil penelitian ini menunjul } \\
\text { bahwa orang dewasa paruh baya } \\
\text { dan muda lebih tinggi peri } \\
\text { manajemen diri dibandingkan } \\
\text { dengan orang tua. Kapasitas u } \\
\text { memahami dan Berkomunikasi bai } \\
\text { kalangan dewasa muda dan kelor } \\
\text { usia menengah tetapi berkurang di } \\
\text { tua kelompok karena gang£ } \\
\text { kognitif. }\end{array}$ \\
\hline
\end{tabular}

No Peneliti Tujuan $\quad \sum \quad$ Disain




\begin{tabular}{|c|c|c|c|c|}
\hline 1 & Andy & Menganalisis & 157 & Cross \\
\hline . & (2012) & faktor-faktor & & sectional \\
\hline & & yang berhubungan & & \\
\hline & & dengan self care & & \\
\hline & & management pada & & \\
\hline 2 & Widho & asuhan keperawatan & 61 & Deskrintif \\
\hline & & - & & \\
\hline . & (2017) & Self Care & & \\
\hline & & pada penderita & & \\
\hline & & Hipertensi di & & \\
\hline & & wilavah keria & & \\
\hline 3 . & Nargis & mengidentifikasi & 110 & Deskriptif \\
\hline & $(2010)$ & tingkat manajemen & & \\
\hline & & diri di antara pasien & & \\
\hline & & dengan & & \\
\hline & & hipertensi & & \\
\hline & & Bangladesh & & \\
\hline
\end{tabular}

Dalam analisa multivariat
didapatkan bahwa faktor yang
paling
signifikan berhubungan dengan
self care management pasien

hinertensi di RSUD Kudus adalah Gambaran self care pada penderita hipertensi di wilayah kerja

Puskesmas Gatak dengan hasil sehaoian hesar denoan kateonri Hasil penelitian ini menunjukkan bahwa orang dewasa paruh baya dan muda lebih tinggi perilaku manajemen diri dibandingkan dengan orang tua. Kapasitas untuk memahami dan Berkomunikasi baik di kalangan dewasa muda. 4. Yuni Penilaian 46 Cross Total dari kepatuhan self management (2019) gambaran Self sectional penderita hipertensi di Puskesmas Management Grogol Kabupaten Sukoharjo dalam Penderita Hipertensi kategori cukup yaitu 31 responden 5. Inda \& Penilaian ${ }^{-} \quad 36$ Cross Ada pengaruh positif yang sangat Nur pengaruh Self sectional signifikan antara self management dengan (2018) Management tekanan darah lansia yang mengalami terhadap tekanan darah Lansia yang hipertensi di Posbindu Dukuhturi Kec. Bumiayu Kab. Brebes. Semakin tinggi self

6. Dasgupta Penilaian praktik 124 Cross Praktik perawatan diri dikaitkan usia, et dan faktor-faktor sectional status ekonomi, tingkat pengetahuan, al., yang dan status pernikahan 
7. Motlagh Penyelidikan 1836Cross Perilaku perawatan diri pasien et perilaku perawatan sectional hipertensi dipengaruhi oleh jenis al., diri kelamin, usia, status pernikahan, tempat 8. Ademe et Penilaian praktik 309 Cross Penilaian praktik perawatan diri pada al., perawatan diri dan sectional pasien hipertensi memiliki hubugan (2019) faktor-faktor terkait terkait status pernikahan, tingkat 9. Ding, Li, Integrasi faktor 268 Cross Tingkat perawatan diri pasien hipertensi $\mathrm{Su}$, terkait manajemen sectional dipengaruhi oleh usia, durasi hipertensi, Yuan, \& diri pasien hipertensi pengetahuan, dukungan sosial, dan efikasi 10.Qu et al., Eksplorasi 873 Cross Manajemen diri pada pasien hipertensi (2019) hubungan antara sectional memiliki faktor yang meliputi usia, jenis manajemen diri kelamin, status pendidikan, status

Hasil analisis dapat terlihat pada tabel 1 tentang gambaran umum penelitian self care managemen hipertensi. Jurnal penelitian adalah tahun 2010 - 2019 dengan jumlah 10 penelitian yang terdiri atas 2 tesis dan 10 jurnal publikasi. Jumlah sampel yang diteliti cukup beragam berkisar dari 36 - 1836 orang. Desain penelitian yang digunakan terdiri dari 8 cross sectional dan 2 penelitian deskriptif. Alat ukur atau instrumen ratarata tidak dicantumkan pada jurnal kecuali 2 jurnal dengan mencantumkan masingmasing 57 item dan 70 item pertanyaan. Hasil identifikasi terhadap faktor risiko penyakit hipertensi dapat dilihat pada tabel 2 .

Tabel 2. Identifikasi faktor risiko penyebab penyakit hipertensi

\begin{tabular}{lccccccccccccc}
\hline \multicolumn{1}{c}{ Variabel/No. Peneliti } & $\mathbf{1}$ & $\mathbf{2}$ & $\mathbf{3}$ & $\mathbf{4}$ & $\mathbf{5}$ & & & & Total \\
\hline Umur & $\sqrt{ }$ & $\sqrt{ }$ & $\sqrt{ }$ & $\sqrt{ }$ & $\sqrt{ }$ & $\sqrt{ }$ & $\sqrt{ }$ & $\sqrt{ }$ & $\sqrt{ }$ & $\sqrt{ }$ & 10 \\
Jenis kelamin & $\sqrt{ }$ & $\sqrt{ }$ & $\sqrt{ }$ & $\sqrt{ }$ & $\sqrt{ }$ & $\sqrt{ }$ & $\sqrt{ }$ & $\sqrt{ }$ & $\sqrt{ }$ & $\sqrt{ }$ & 10 \\
Pendidikan & $\sqrt{ }$ & $\sqrt{ }$ & $\sqrt{ }$ & $\sqrt{ }$ & $\sqrt{ }$ & $\sqrt{ }$ & $\sqrt{ }$ & $\sqrt{ }$ & $\sqrt{ }$ & $\sqrt{ }$ & 10 \\
Pekerjaan & - & $\sqrt{ }$ & $\sqrt{ }$ & $\sqrt{ }$ & $\sqrt{ }$ & $\sqrt{ }$ & $\sqrt{ }$ & $\sqrt{ }$ & $\sqrt{ }$ & $\sqrt{ }$ & 9 \\
Penghasilan & - & $\sqrt{ }$ & $\sqrt{ }$ & $\sqrt{ }$ & - & $\sqrt{ }$ & $\sqrt{ }$ & $\sqrt{ }$ & $\sqrt{ }$ & $\sqrt{ }$ & 8 \\
Jumlah anak & - & $\sqrt{ }$ & $\sqrt{ }$ & - & - & $\sqrt{ }$ & - & $\sqrt{ }$ & $\sqrt{ }$ & $\sqrt{ }$ & 6 \\
Lingkungan tempat tinggal & - & - & $\sqrt{ }$ & - & - & $\sqrt{ }$ & $\sqrt{ }$ & $\sqrt{ }$ & $\sqrt{ }$ & $\sqrt{ }$ & 6 \\
Riwayat penyakit & $\sqrt{ }$ & $\sqrt{ }$ & $\sqrt{ }$ & $\sqrt{ }$ & $\sqrt{ }$ & $\sqrt{ }$ & $\sqrt{ }$ & $\sqrt{ }$ & $\sqrt{ }$ & $\sqrt{ }$ & 10
\end{tabular}




$\begin{array}{lccccccccccc}\text { Riwayat keluarga } & - & \sqrt{ } & - & - & - & \sqrt{ } & \sqrt{ } & \sqrt{ } & \sqrt{ } & \sqrt{ } & 6 \\ \text { Merokok } & \sqrt{ } & \sqrt{ } & \sqrt{ } & \sqrt{ } & \sqrt{ } & \sqrt{ } & \sqrt{ } & \sqrt{ } & \sqrt{ } & \sqrt{ } & 10 \\ \text { IMT } & \sqrt{ } & \sqrt{ } & \sqrt{ } & \sqrt{ } & - & \sqrt{ } & \sqrt{ } & \sqrt{ } & \sqrt{ } & \sqrt{ } & 9 \\ \text { Pengetahuan } & \sqrt{ } & \sqrt{ } & \sqrt{ } & \sqrt{ } & - & \sqrt{ } & - & \sqrt{ } & \sqrt{ } & \sqrt{ } & 8 \\ \text { Sikap } & \sqrt{ } & \sqrt{ } & \sqrt{ } & \sqrt{ } & \sqrt{ } & \sqrt{ } & \sqrt{ } & \sqrt{ } & \sqrt{ } & \sqrt{ } & 10 \\ \text { Motivasi } & \sqrt{ } & \sqrt{ } & \sqrt{ } & \sqrt{ } & \sqrt{ } & \sqrt{ } & - & \sqrt{ } & \sqrt{ } & \sqrt{ } & 9 \\ \text { Pola makan } & \sqrt{ } & \sqrt{ } & \sqrt{ } & \sqrt{ } & \sqrt{ } & \sqrt{ } & \sqrt{ } & \sqrt{ } & \sqrt{ } & \sqrt{ } & 10 \\ \text { Alkohol } & \sqrt{ } & \sqrt{ } & \sqrt{ } & \sqrt{ } & \sqrt{ } & \sqrt{ } & \sqrt{ } & \sqrt{ } & \sqrt{ } & \sqrt{ } & 10 \\ \text { Aktivitas fisik } & \sqrt{ } & \sqrt{ } & \sqrt{ } & \sqrt{ } & \sqrt{ } & \sqrt{ } & \sqrt{ } & \sqrt{ } & \sqrt{ } & \sqrt{ } & 10 \\ \text { Status pasangan } & - & \sqrt{ } & \sqrt{ } & - & - & \sqrt{ } & \sqrt{ } & \sqrt{ } & \sqrt{ } & \sqrt{ } & 7 \\ \text { Konsumsi garam } & \sqrt{ } & \sqrt{ } & \sqrt{ } & \sqrt{ } & \sqrt{ } & \sqrt{ } & \sqrt{ } & \sqrt{ } & \sqrt{ } & \sqrt{ } & 10 \\ \text { Konsumsi lemak } & \sqrt{ } & \sqrt{ } & \sqrt{ } & \sqrt{ } & \sqrt{ } & \sqrt{ } & \sqrt{ } & \sqrt{ } & \sqrt{ } & \sqrt{ } & 10 \\ \text { Stress } & \sqrt{ } & \sqrt{ } & \sqrt{ } & \sqrt{ } & \sqrt{ } & \sqrt{ } & \sqrt{ } & \sqrt{ } & \sqrt{ } & \sqrt{ } & 10 \\ \text { Konsumsi obat } & \sqrt{ } & \sqrt{ } & \sqrt{ } & \sqrt{ } & \sqrt{ } & \sqrt{ } & \sqrt{ } & \sqrt{ } & \sqrt{ } & \sqrt{ } & 10 \\ \text { Pemantauan tekanan darah } & \sqrt{ } & - & \sqrt{ } & \sqrt{ } & \sqrt{ } & \sqrt{ } & \sqrt{ } & \sqrt{ } & \sqrt{ } & \sqrt{ } & 9 \\ \text { Total } & 17 & 21 & 22 & 18 & 16 & 23 & 20 & 23 & 23 & 23 & \end{array}$

Banyak faktor yang berisiko terhadap kejadian hipertensi antara lain faktor genetik, faktor asupan, faktor gaya hidup dan faktor pelayanan kesehatan. Pada tabel 2 menunjukkan faktor risiko penyebab penyakit hipertensi yang paling banyak diteliti adalah variabel umur, jenis kelamin, pendidikan riwayat penyakit merokok, sikap, pola makan, alkohol, aktivitas fisik, konsumsi garam, konsumsi lemak, stres, dan konsumsi obat antihipertensi sebanyak 10 dari 23 jumlah variabel. Disusul oleh variabel pekerjaan, IMT, motivasi, dan pemantauan tekanan darah sebanyak 9, selanjutnya variabel penghasilan dan pengetahuan sebanyak 8. Faktor risiko lainnya adalah variabel status pasangan 7 dan jumla anak, lingkungan tempat tinggal, dan riwayat keluarga masing-masing hanya 6 penelitian. Sedangkan berdasarkan hasil penelitian self care management pada pasien hipertensi dapat terlihat pada tabel 3 berikut.

Tabel 3. Identifikasi self care management pada pasien hipertensi

\begin{tabular}{llccc}
\hline & & \multicolumn{4}{l}{ Hasil penelitian self care management } \\
\cline { 3 - 5 } No & Peneliti & $\sum_{\text {Sampe }}$ & Kurang Baik & $\sum$ \\
& & & Sampel \\
\hline
\end{tabular}




\begin{tabular}{|c|c|c|c|c|c|}
\hline \multirow[t]{2}{*}{1.} & \multicolumn{5}{|l|}{ Andy } \\
\hline & & $31 \%$ & 49 & $69 \%$ & 108 \\
\hline 2. & Widho & & & & \\
\hline & & $82 \%$ & 50 & $18 \%$ & 11 \\
\hline 3. & Nargis & & & & \\
\hline & & $45,8 \%$ & 50 & $54,2 \%$ & 60 \\
\hline 4. & Yuni & $79,3 \%$ & 36 & $21,7 \%$ & 10 \\
\hline 5. & Inda \& nur & $63.9 \%$ & 23 & $36,1 \%$ & 13 \\
\hline 6. & Dasgupta et al & $38,8 \%$ & 42 & $61,2 \%$ & 82 \\
\hline 7. & Motlagh et al & $33,1 \%$ & 608 & $66,9 \%$ & 1.228 \\
\hline 8. & Ademe et al & $49 \%$ & 151 & $51 \%$ & 158 \\
\hline 9. & $\begin{array}{l}\text { Ding, Li, Su, Yuan, \& } \\
\text { Lin }\end{array}$ & $82 \%$ & 220 & $18 \%$ & 48 \\
\hline 10 & $\begin{array}{l}\text { Qu et al., } \\
\text { Persentase }\end{array}$ & $\begin{array}{l}61 \% \\
\mathbf{5 6 , 5} \%\end{array}$ & 533 & $\begin{array}{l}39 \% \\
\mathbf{4 3 , 5} \%\end{array}$ & 340 \\
\hline
\end{tabular}

Tabel 3 menunjukkan beberapa variabel yang diteliti mengenai self care management hipertensi. Dari beberapa penelitian didapatkan self care management pasien hipertensi memiliki persentasi baik sebesar 56,5\% dan kurang baik sebesar $43,5 \%$, dari hasil tersebut menunjukan pasien hipertensi sudah banyak melalukan self care management. Self care management pasien hipertensi yang signifikan dilakukan dengan persentase diatas $50 \%$ dengan baik terdapat $5(2,4,5,9,10)$ penelitian dan 5 $(1,3,6,7,8)$ penelitian dengan persentasi dibawah 50\%. Persentase self care management yang signifikan baik tertinggi pada penelitian nomor 2 dan 9 dengan persentase 82 persen, disusul penelitian 4, 5, dan $10(79,3 \%, 63,9 \%, 61 \%)$. Penelitian dengan self care management signifikan kurang baik 1 (69\%), 3 (54,2\%), 6 (61,2\%), $7(66,9 \%), 8(51 \%)$.

\section{PEMBAHASAN}

1. Monitoring Tekanan Darah 
Salah satu upaya untuk melakukan pencegahan komplikasi hipertensi perlu adanya peningkatan pencegahan tentang hipertensi dengan melakukan pengukuran tekanan darah. Pengkuran ini sangat penting untuk mengetahui tingkat keberhasilan atau kekambuhan dari penyakit hipertensi yang dideritanya. Hal ini sesuai dengan pendapat Koizer,et al, (2010) tingkat kepatuhan dapat dimulai dari tindak mengindahkan dari setiap aspek anjuran hingga mematuhi semua rencana terapi, termasuk dalam kepatuhan melakuklan pemeriksaan tekanan darah. pemantauan dari pengobatan antihipertensi biasanya dilakukan dengan pengukuran tekanan darah di tempat pelayanan kesehatan seperti puskesmas ataupun poliklinik di rumah sakit dengan hasil dua kali kunjungan diatas 140/90 menurut Seventh Report of the Joint National Committee on Prevention, Detection, Evaluation, and Treatment of High Blood Pressure, (2004).

\section{Aktivitas fisik dan berat badan}

Melakukan kegiatan sehari-sehari sudah termasuk dalam aktifitas fisik, selain itu aktifitas fisik adalah suatu kegiatan yang murah, mudah dan menyehatkan. Aktivitas fisik memiliki efek pada penurunan berat badan berlebih. Rekomendasi aktivitas fisik yang dianjurkan meliputi olahraga, aerobik, dan latihan ketahanan otot. Penurunan berat badan hingga 10 kilogram $(\mathrm{Kg})$ menunjukkan hasil pengurangan tekanan darah hingga $6 \mathrm{mmHg}$ sistolik dan 4,6 $\mathrm{mmHg}$ diastolik pada pasien dengan hipertensi (Aucott et al., 2005; Diaz and Shimbo, 2013). Penurunan berat badan memiliki efek pada pengurangan massa dan ketebalan dinding ventrikel kiri, memperbaiki fungsi arteri dan peningkatan fungsi endotel (Earnest \& Church, 2016)

\section{Modifikasi Diet}

Mengurangi asupan garam, memperbanyak serat, menghentikan kebiasaan buruk seperti merokok, minum kopi, mengkonsumsi alcohol, memanfaatkan sayuran dan bumbu dapur serta mengkonsumsi obat secara teratur akan membantu dalam menurunkan tekanan darah. 


\section{a. Konsumsi Garam}

Konsumsi garam berlebih memiliki efek negatif pada tekanan darah. Asupan garam yang tinggi dapat meningkatkan tekanan darah (Subasinghe et al., 2016). Pengurangan asupan garam pada pasien hipertensi dapat menurunkan tekanan darah sebesar $5 \mathrm{mmHg}$ sistolik (Suckling, He, Markandu, \& Macgregor, 2016). Pengurangan konsumsi garam sebanyak 4,4 gram/hari dapat menurunkan tekanan Tinjauan Literatur 270 darah dalam rentang 3,18 - 5,18 $\mathrm{mmHg}$ sistolik dan 1,45 - 2,67 mmHg diastolik (Frisoli, Schmieder, Grodzicki, \& Messerli, 2012).

b. Alkohol

Minuman yang mengandung alkohol memiliki efek buruk pada tekanan darah. Konsumsi alkohol yang berlebihan dapat meningkatkan tekanan darah dengan fisiologi terjadinya peningkatan aktivitas sistem saraf simpatik yang kemudian mengeluarkan atau sekresi hormon kortikotropin sehingga terjadi ketidakseimbangan pada sistem saraf pusat yang menyebabkan ganguan pada output jantung (F. Loyke, 2013; Husain, Ansari \& Ferder, 2014; Roerecke et al., 2017).

\section{c. Merokok}

Klien hipertensi yang merokok dan terpapar asap rokok memiliki peluang terhadap faktor risiko gejala kardiovaskuler (Whelton et al., 2018). Belum ada kejelasan terkait peningkatan tekanan darah pada individu yang merokok dan tidak

merokok (Freitas \& Alvim, 2017). Namun berbeda dengan pendapat Al-safi, (2005) yang mengeksplorasi hubungan kebiasaan merokok dengan tekanan darah menemukan perokok memiliki lebih banyak tekanan darah tinggi daripada individu yang tidak merokok.

\section{c. Konsumsi Kopi}

Kopi merupakan salah satu penyebab terjadinya peningkatan tekanan darah (Mesas, Munoz, Rodriguez Artalejo, \& Lopez Gracia, 2011). Dosis kafein yang tinggi pada kopi, menyebabkan peningkatan tekanan darah pada pasien hipertensi (Hartley et al., 2000). Kandungan kopi tidak hanya kafein saja, namun beberapa zat lain yang ada 
didalam kopi meliputi polifenol, serat larut dan kalium yang memiliki efek positif pada sistem kardivaskuler (Geleijnse, 2008).

\section{Management Stress}

Praktik manajemen stres bermanfaat bagi penurunan tekanan darah seperti melakukan meditasi, relaksasi otot progresif, latihan pernapasan dan terapi musik untuk menurunkan stres (Whelton et al., 2018). Relaksasi oto progresif memiliki efek penurunan tekanan darah sistolik dan diastolik masing-masing 5,44 $\mathrm{mmHg}$ dan 3,48 mmHg (Sheu, Irvin, Lin, \& Mar, 2003). Intervensi perilaku kognitif terstruktur dapat mengurangi stres pada pasien hipertensi yang dapat memberi manfaat pada pengurangan tekanan darah sistolik $7,5 \mathrm{mmHg}$, sedangkan pada diastolik tidak terjadi penurunan (Clemow et al., 2018).

\section{Minum Obat Teratur}

Kepatuhan minum obat secara efektif dapat meningkatkan kualitas hidup, kemudian ketidak patuhan menjadi faktor kegagalan dalam pelaksanaan manajemen terapi. Kepatuhan yang rendah dapat menyebabkan resistensi obat antihipertensi sehingga manfaat untuk melakukan perawatan diri mengalami penurnan, dibutuhkan inisiasi, tindakan serta ketekunan untuk tetap menjalankan rejimen pengobatan (Vrijens, Antoniou, Burnier, \& Sierra, 2017). responden yang telah mengalami komplikasi menyebabkan individu tersebut dalam mematuhi komsumsi obatnya tinggi, karena adanya komplikasi dapat menurunkan kualitas hidup seseorang(Kim, Yoon, Oh, Lim \& Kim, 2016), oleh karena itu faktor pengalaman akan sangat mempengaruhi seseorang menjalankan kepatuhan dalam komsumsi obat.

\section{SIMPULAN}

Perawatan diri adalah rangkaian tindakan yang dengan tujuan untuk penurunan tekanan darah. Tindakan praktik perawatan diri itu sendiri memiliki berbagai jenis praktik perawatan yang meliputi diet rendah garam, mengurangi konsumsi kafein, 
mengurangi konsumsi alkohol, melakukan aktivitas fisik, manajemen berat badan, manajemen stres, dan mematuhi rejimen pengobatan. Berdasarkan hasil penelitian menunjukan banyak pasien hipertensi yang sudah mampu melakukan self care management dengan baik (57\%) dan yang belum mampu melakukan self care management dengan baik (43\%). Penelitian lebih lanjut diperlukan untuk memberikan strategi intervensi pada pasien hipertensi agar meningkatkan praktik perawatan diri dan pengendalian faktor-faktor terkait.

\section{SARAN}

Diharapkan dapat meningkatkan self efficacy bagi pasien dengan pendekatan keluarga.

\section{UCAPAN TERIMA KASIH}

Akhirnya tibalah di bagian terakhir dari artikel ini kami mengucapkan terimakasih kepada Bapak Dekan FMIPA Universitas Bengkulu, Bapak Ka.Prodi D3 Keperatawatan, Bapak Ketua LPPM dan semua pihak yang terlibat dalam membantu menyelesaikan penulisan penelitian dengan pendekatan sistematik review.

\section{DAFTAR RUJUKAN}

Ademe, S., Aga, F., \& Gela, D. (2019). Hypertension self-care practice and associated factors among patients in public health facilities of dessie town , Ethiopia. BMC Health Services Research, 19:51(1), 1-9. https://doi.org/10.1186/s12913-019-3880-0

Akhter, Nargis. 2010. Self management among patient with hypertension in bangladesh. Songkla: Songkla University

Bandura, A. 1997. Self-efficacy: the exercise of control. W.H. Freeman

Black, M. J. And Hawks, H. J. 2009. Medical surgical nursing : clinical management for continuity of care. Philadephia : W.B. Saunders Company. 
Cahyani, Yuni Eka.2019. Gambaran self management penderita hipertensi di puskesmas grogol kabupaten sukoharjo. Universitas Muhammadiyah Surakarta: Naskah Publikasi.

Corwin, Elizabeth, J. 2009. Buku saku patofisiologi. Jakarta: Buku Kedokteran EGC.

Dasgupta, A., Sembiah, S., Paul, B., Ghosh, A., Biswas, B., Mallick, N., ... Health, P. (2018). Assessment of self-care practices among hypertensive patients : a clinic based study in rural area of singur, west bengal. international journal of community medicine and public health, 5(1), 262-267. https://doi.org/10.18203/2394- 6040.ijcmph20175794.

Ding, W., Li, T., Su, Q., Yuan, M., \& Lin, A. (2018). Integrating factors associated with hypertensive patients 'self- management using structural equation modeling: a cross-sectional study in guangdong, china. journal of patient preference and adherence,12,2169-2178. https://doi.org/10.2147/PPA.S180314.

Fahkurnia, Widho.2017. Gambaran Selfcare Pada Penderita Hipertensi Di Wilayah Kerja Puskesmas Gatak Kabupaten Sukoharjo. Universitas Muhammadiyah Surakarta: Https://Naspub- Libraryums-Widho.

Isnaini, Nur \& Lestari, Inda Galuh. 2018. Pengaruh Self Management Terhaap Tekanan Darah Lansia Yang Mengalami Hipertensi. Universitas Muhammadiyah Purwokerto: Indonesian Journal For Health Sciences.

Ismani, N. 2001. Etika Keperawatan. Jakarta: Widya Medika.

Kementerian Kesehatan Republik Indonesia. 2019. Hari Hipertensi Dunia 2019: Know Your Number, Kendalikan Tekanan Darahmu Dengan Cerdik. (Http://P2ptm.Kemkes.Go.Id/ Diakses 21 Januari 2020).

Klabunde, Richard. E. 2015. Konsep Fisiologi Kardiovaskular, ED. 2. Jakarta: Buku Kedokteran EGC.

Kowalak, Jennifer. P., Welsh, William., And Mayer, Brenna. 2017. Buku Ajar Patofisiologi. Jakarta: Buku Kedokteran EGC.

Lemone., Priscilla., Burke., Karem., Bauldoff., And Gerene. 2019. Buku Ajar Keperawatan Medikal Bedah Gangguan Kardiovaskular. Jakarta: Buku Kedokteran EGC.

Lin, C., Anderson, RM, Chang, C., Hagerty, BM, \& Cherry, L. (2008). Pengembangan Dan Pengujian Instrumen Swa-Manajemen Diabetes: Analisis Konfirmasi. Penelitian Di Keperawatan \& Kesehatan, 31, 370-380. 
Motlagh, S. F. Z., Chaman, R., Sadeghi, E., \& Eslami, A. A. (2016). Self- Care Behaviors and Related Factors in Hypertensive Patients. Iranian Red Crescent Medical Journal, 18(6), 1-10. https://doi.org/10.5812/ircmj.35805.

Muttaqin, Arif. 2012. Buku Ajar Asuhan Keperawatan Klien Dengan Gangguan Sistem Kardiovaskular Dan Hematologi. Jakarta: Salemba Medika.

Notoatmodjo, S. 2010. Ilmu Perilaku Kesehatan. Jakarta: Rineka Cipta.

Nursalam. 2009. Konsep Dan Peneraapan Metodologi Penelitian Ilmu Keperawatan. Jakarta: Salemba Medika.

Nwinee, J. P. 2011. Nwinee Socio-Behaveoural Self-Care Management Nursing Model.West African Journal Of Nursing.

Prastyo, Andy Sofyan. 2012. Analisis Faktor Faktor Yang Berhubungan Dengan Self Care Management Pada Asuhan Keperawatan Pasien Hipertensi Di Rsud Kudus. Jakarta: Universitas Indonesia.

Qu, Z., Parry, M., Liu, F., Wen, X., Li, J., Zhang, Y., ... Li, X. (2019). SelfManagement and Blood Pressure Control in China: a Community-Based Multicentre Cross-Sectional Study. Nursing Research, 1-11. https://doi.org/10.1136/bmjopen-2018- 025819 